\title{
Editors' Introduction: Socio-Cultural and Political Changes in South Korea through a Discursive Lens*
}

Timothy C. Lim**, Changzoo Song***

It is fair to say that South Korea has been undergoing a lot of changes, both big and small, over the past few decades. One of the most salient is the gradual but still quite noticeable transition from an outwardly homogenous society into a multi-ethnic and multicultural one - that is, into a society that acknowledges, rather than hides, the empirical fact or reality of (growing) ethnic and racial diversity. This growing ethnic and racial diversity, as most observers know, is due to rising immigration composed of both labor migrants and so-called marriage migrants. It is a trend that began in the late 1980s and which shows little to no signs of abating after more than three decades. Moreover, given the country's remarkably low fertility rate of just 0.84 in 2020 and aging demographic profile, ${ }^{1}$ the

* This work was written with the support of two separate grants through the Ministry of Education of the Republic of Korea and the Korean Studies Promotion Service of the Academy of Korean Studies: (1) The Laboratory Program for Korean Studies (AKS-2018-LAB-2250001), and (2) Core University Program for Korean Studies (AKS-2017-OLU-2250001).

** Corresponding author. Professor of Political Science at California State University, Los Angeles. E-mail: tclim@calstatela.edu

*** Senior Lecturer in Korean/Asian Studies at University of Auckland. E-mail: ch.song@auckland.ac.nz

1 For a basic discussion of South Korea's demographic challenges, see Chung Min Lee and Kathryn Botto, "Demographics and the Future of South Korea," Carnegie 
need for more immigrants is likely to grow increasingly urgent over time. Neither the empirical fact of expanding diversity or a declining and aging population, though, necessarily means that South Korea has mostly, much less fully, accepted the inevitability of a transition to a multi-ethnic and multicultural society. Indeed, as two of the papers in this special issue highlight, a significant portion of rising immigration to South Korea is composed of ethnic Koreans, mostly from China; other parts of the Korean diaspora have also been part of this process. The general effort on the part of the South Korean government to encourage greater immigration among co-ethnics reflects the long-standing importance placed on maintaining ethnic and racial homogeneity (or ethnonationalism), an ethos that the country's leaders have, until recently, unremittingly promoted and reproduced (i.e., socially constructed) since the inception of South Korea as a sovereign state and, actually, long before then under Japan's colonial rule. $^{2}$ For their part, too, the decision by ethnic Koreans to emigrate to South Korea, whether temporarily or on a permanent basis, at least partly reflects a feeling of kinship, even if not always genuinely felt. ${ }^{3}$

We will return to the last point shortly, but first a quick but important aside. Ideally, this special issue would have included one or several articles on immigrants who most clearly reflect the transition to a multiethnic and multicultural society. Unfortunately, we weren't able to do this. Simply put, we did not find contributors who could write about those communities for this special issue. Thus, the lack of a contributions on marriage migrants from, say, Vietnam ${ }^{4}$ or the Philippines ${ }^{5}$, or a contribu-

Endowment for International Peace, June 29 2021, https://carnegieendowment.org /2021/06/29/demographics-and-future-of-south-korea-pub-84817.

2 Gi-Wook Shin, Ethnic Nationalism in Korea: Genealogy, Politics, and Legacy (Stanford: Stanford University Press, 2006).

3 Caren Freeman, Making and Faking Kinship: Marriage and Labor Migration between China and South Korea (Ithaca: Cornell University Press, 2011).

4 For example, see Hee-Kang Kim "Marriage Migration between South Korea and Vietnam: A Gender Perspective," Asian Perspective 36, no. 3 (2012). Kim writes about marriage migration between South Korea and Vietnam from a gendered per- 
tion on the struggle by foreign workers from South and Southeast Asia for greater institutional recognition, ${ }^{6}$ is not because we consider those topics less worthy of attention. Instead, it is only because of our own less-than successful efforts and because of the vagaries of trying to organize a special journal issue of this nature. This said, there is a lot of existing research and writing on those topics, some of which we have already mentioned in footnotes. It would be useful to add a bit to that list. On the struggle for labor rights by immigrant workers in South Korea, a recent and in-depth analysis is provided by Joon K. Kim, in his book, Organized Labor and Civil Society for Multiculturalism: A Solidarity Success Story from South Korea. In an even more recent article, Ilju Kim writes about the dual citizenship claims (or the lack of such claims) among marriage migrant women from the Philippines and Vietnam in South Korea. ${ }^{7}$ One of the guest editors, Timothy Lim, has also written a book, The Road to

spective. Another, more recent analysis is provided by Kim and Shin "Governing through Mobilities and the Expansion of Spatial Capability of Vietnamese Marriage Migrant Activist Women in South Korea," Singapore Journal of Tropical Geography 39, no. 3 (2018). They focus on Vietnamese marriage migrant activist women in South Korea.

5 For an in-depth study of Filipina marriage migrants, see Minjeong Kim, Elusive Belonging: Marriage Immigrants and "Mulitculturalism" in Rural South Korea (Honolulu: University of Hawaii Press, 2018). Also, see Mahgie Bual Lacaba, "Global Imagination and Agency Formation of Filipino Marriage Migrant Women in South Korea," The Review of Korean Studies 21, no. 2 (2018).

6 For some early examples, see Timothy C. Lim, "Racing from the Bottom in South Korea?: The Nexus between Civil Society and Transnational Migrants," Asian Survey 43, no. 3 (2003); Dong-Hoon Seol and John D. Skrentny, "South Korea: Importing Undocumented Workers," in Controlling Immigration: A Global Perspective, ed. Wayne A. Cornelius, et al. (Stanford: Stanford University Press, 2004); Wang-Bae Kim, "Migration of Foreign Workers into South Korea: From Periphery to Semi-Periphery in the Global Labor Market," Asian survey 44, no. 2 (2004).

7 Ilju Kim and Minjeong Kim, "Paths to Civic Engagement," Journal of Asian Sociology 50, no. 1 (2021). 
Multiculturalism in South Korea, that covers the transition to a multicultural society in a comprehensive fashion.

Returning to the main point: On the surface, rather than bringing about far-reaching socio-cultural and political change, rising immigration appears to be reinforcing the ethnonationalist status quo. There is certainly more than a little truth to this point. On the ground, however, the issue is more complicated as the South Korean state has not treated all ethnic Koreans equally. In an important sense, one can argue, some ethnic Koreans were essentially defined as non-Korean; more accurately, though, the South Korean government initially determined that they were not entitled to the same immigration status as other ethnic Koreans despite their "shared blood" ties. A major reason for this, according to some scholars, is the strong class bias among policymakers and within South Korean society more generally. ${ }^{8}$ This bias quite likely served as an important, albeit not the sole, ${ }^{9}$ basis for relegating certain members of the Korean diaspora-i.e., those from relatively poor regions in China and Central Asia (former Soviet states such as Uzbekistan and Kazakhstan) - to second class status, compared to members from wealthier parts of the diaspo$\mathrm{ra}$, in the context of South Korea's immigration and naturalization regime. Surprisingly, this unequal treatment has resulted in serious and ongoing tension in the relationship between "poor cousin" ethnic Koreans, especially Korean Chinese or Chosŏnjok, and the South Korean state and society. We say "surprisingly" because Korean Chinese are, after all, are citizens of China; they are, in a word, "foreigners." Yet, why should "foreigners"- and relatively poor foreigners, to boot-expect a sovereign state to care about or cater to their interests?

One overly simple answer is this: Korean Chinese don't consider themselves to be foreigners in South Korea. This point is, in fact, brought

8 See, for example, Nora Hui-Jung Kim, "Flexible yet Inflexible: Development of Dual Citizenship in South Korea," Journal of Korean Studies 18, no. 1 (2013).

9 Other factors are discussed in the contribution by Lim and Song in this special issue. 
front-and-center by Yang-Sook Kim and Yi-Chun Chien in their aptly titled article, “We Are Not Foreigners': Constructing Migrant Subjects through Korean Chinese Migrants' Claim-Making in South Korea.” The two authors argue, in part, that Korean Chinese activists have not only challenged their unequal treatment by the South Korean government, but also premised their challenge on the claim that they are entitled to preferential treatment (compared to "foreigners") in virtue of their shared Korean blood or as ethnic kin. Additionally, their challenge has entailed a conscious decision to detach themselves from the mainstream rights movement led by South Korean activists and (non-co-ethnic) immigrant workers. Consequently, Kim and Chien assert, Korean Chinese activists have come to "embody a hierarchical nationhood to navigate the normalized racism and ethnocentrism in South Korean society." Despite their conclusion, which points to a significant degree of "ethnonationalist continuity," the effort to actively incorporate parts of the Korean diaspora not only required but also led to additional and increasingly significant political or institutional change. Part of this change, it is fair to say, was due to demographic and concomitant material pressures, but another part was due to individual and collective agency exercised by both South Korean citizens and non-citizens, who persuaded the South Korean government to create a more inclusive immigration and naturalization regime than originally intended.

These issues are addressed by the co-editors in their contribution to this issue, "Ideas, Discourse, and the Microfoundations of South Korea's Diasporic Engagement: Explaining the Institutional Embrace of Ethnic Korean Since the 1990s." Whereas the article by Kim and Chien focuses primarily on the subjectivity and agency of Korean Chinese, we adopt a contrasting approach by primarily, but not wholly, focusing on (the subjectivity of) actors within the state and in mainstream South Korean society. The two approaches are largely complementary, particularly in terms of their ideational and discourse-based theoretical framework. More specifically, we argue that ideational and discursive efforts by key agents (or discursive agents)—state actors, business leaders, academics, journalists, 
judges, religious leaders, and members of the diasporic communitieshelped to build a framework for the emergence of "diaspora engagement institutions" that, until the late-1990s, had not existed at all. The emergence of these institutions, of which the Overseas Koreans Act (OKA) is the cornerstone, was premised on a fundamental reframing of ethnic Koreans as "brethren" and "national assets," which, we contend, was a powerful discursive combination. Again, on the surface, this suggests less change and more of the same in terms of the centrality of ethnonationalism. However, as we discuss in our paper, the issue is more complicated; in addition, the institutional incorporation of the Korean diaspora represented a significant change toward the "deterritorialization" of the Korean nation-state. ${ }^{10}$

While two of the articles in this special issue focus on changes involving ethnic Koreans, two others deal with two very different changes. In one, Wondong Lee examines LGBT issues in South Korea, while Ray Kim looks at the government's efforts to "strategize entering the rapidly expanding Islamic economy ...". Both authors, moreover, are primarily concerned with the social backlash-from evangelical Christians specifically - that resulted from the ostensible embrace of hitherto marginalized communities in South Korea, although in the latter case, engagement with the Islamic community arguably had more to do with taking advantage of global market trends than an acceptance of the community itself. Nonetheless, the motivation for engaging with the halal market in the first place, as Kim succinctly puts it, is a "truly glocal matter," signifying the effort to gain a foothold in an increasingly global market while "simultaneously wrestling with questions about multiculturalism" within South Korean society. The same could be said of rising prominence of LGBT issues, which reflects both liberal trends at the global level, and also local-level social and political dynamics. The evangelical backlash, in turn, draws from both the local and global levels, as both authors skillfully

10 For further discussion, see Changzoo Song, "Engaging the Diaspora in an Era of Transnationalism," IZA World of Labor 64 (2014). 
discuss. It is worth noting, too, that Lee and Kim focus on the discursive strategies used by evangelical leaders as a way to frame their opposition to LGBT rights and halal (and Islam more broadly) respectively.

The discursive or discourse-based approaches employed by Wondong Lee and Ray Kim help to connect all the papers in this special issue. Yang-Sook Kim and Yi-Chun Chien, in dealing with the sense of entitlement of Chosónjok migrants, look at the use of a "biological" discourse, to cite one salient example from their analysis, on which the host society's sense of nationhood is anchored. Our paper on the institutional embrace of Korean diaspora after the 1990s is also built on the discourse that emphasizes the supposedly innate, but only recently discovered, "value" of the Korean diaspora. We argue that a few "visionary" people (albeit with a healthy dose of self-interest and instrumentalism in some cases), exercising their discursive agency, played essential roles in creating the South Korean state's post-1990s diasporic engagement policy. Ray Kim's paper on the halal debate in the last decade in South Korea analyzes the conflicting discourses of the business-oriented entities (state and business) and politically conservative evangelical churches. Finally, Wondong Lee examines how evangelical elites in South Korea have adopted and employed a fluid, multifaceted, and sophisticated discursive strategy to influence public opinion as well as state actors.

In sum, all of the papers chosen for this special issue provide useful insights into ongoing change in South Korea, even if some of this change, at least on the surface, suggests "business as usual." It is clear, though, that diasporic engagement, debates over who qualifies as Korean (or who benefits from Korean ethnicity), LGBT rights, multiculturalism, the growing influence of evangelical Christianity, efforts to enter the global halal market, all tell us that significant change has been taking place in South Korea. Much of this change, moreover, is rooted in a simultaneously local and global ("glocal") discursive process involving a range of actors. As the four papers help to highlight, this discursive process is not just composed of empty or meaningless talk. Quite the contrary. Ideas and the discourse that forms around those ideas fundamentally shape the direction 
of socio-cultural change, which in turn, shapes formal policies and political change more generally.

\section{References}

1. Freeman, Caren. Making and Faking Kinship: Marriage and Labor Migration between China and South Korea. Ithaca: Cornell University Press, 2011. doi:10.7591/j.ctt7z7kg.

2. Kim, Hee-Kang. "Marriage Migration between South Korea and Vietnam: A Gender Perspective." Asian Perspective 36, no. 3 (2012): 531-63.

3. Kim, Ilju, and Minjeong Kim. "Paths to Civic Engagement." Journal of Asian Sociology 50, no. 1 (March 2021): 247-72.

4. Kim, Joon K. Organized Labor and Civil Society for Multiculturalism: A Solidarity Success Story from South Korea. Bingley: Emerald Publishing Limited, 2020.

5. Kim, Minjeong. Elusive Belonging: Marriage Immigrants and "Mulitculturalism" in Rural South Korea. Honolulu: University of Hawaii Press, 2018.

6. Kim, Nora Hui-Jung. "Flexible yet Inflexible: Development of Dual Citizenship in South Korea." Journal of Korean Studies 18, no. 1 (2013): 7-28.

7. Kim, Wang-Bae. "Migration of Foreign Workers into South Korea: From Periphery to Semi-Periphery in the Global Labor Market." Asian survey 44, no. 2 (2004): 316-35.

8. Kim, Yulii, and HaeRan Shin. "Governing through Mobilities and the Expansion of Spatial Capability of Vietnamese Marriage Migrant Activist Women in South Korea." Singapore Journal of Tropical Geography 39, no. 3 (2018): 364-81.

9. Lacaba, Mahgie Bual. "Global Imagination and Agency Formation of Filipino Marriage Migrant Women in South Korea." The Review of Korean Studies 21, no. 2 (2018): 65-85. 
10. Lee, Chung Min, and Kathryn Botto. "Demographics and the Future of South Korea." Carnegie Endowment for International Peace, June 29 2021. https://carnegieendowment.org/2021/06/29/demographicsand-future-of-south-korea-pub-84817.

11. Lim, Timothy C. "Racing from the Bottom in South Korea?: The Nexus between Civil Society and Transnational Migrants." Asian Survey 43, no. 3 (2003): 423-42.

12. . The Road to Multiculturalism in South Korea: Ideas, Discourse, and Institutitonal Change in a Homogenous Nation-State. London and New York: Routledge, 2021.

13. Seol, Dong-Hoon, and John D. Skrentny. "South Korea: Importing Undocumented Workers." In Controlling Immigration: A Global Perspective, edited by Wayne A. Cornelius, Tsuda Takeyuki, Philip L. Martin and James F. Hollifield, 481-513. Stanford: Stanford University Press, 2004.

14. Shin, Gi-Wook. Ethnic Nationalism in Korea: Genealogy, Politics, and Legacy. Stanford: Stanford University Press, 2006.

15. Song, Changzoo. "Engaging the Diaspora in an Era of Transnationalism." IZA World of Labor 64 (2014): 1-10. 
